\title{
Barriers for Introgression of Solanum ochranthum into Tomato via Somatic Hybrids
}

\author{
John R. Stommel ${ }^{1}$ \\ U.S. Department of Agriculture, Agricultural Research Service, Vegetable Laboratory, Building 010-A, \\ BARC-West, 10300 Baltimore Avenue, Beltsville, MD 20705
}

\begin{abstract}
AdDITIONAL INDEX wORDs. intergeneric hybrids, Lycopersicon esculentum, plant breeding, wide hybridization
Abstract. Solanum ochranthum Dunal is a nontuber bearing wild relative of the cultivated tomato (Lycopersicon esculentum Mill.), and a potential source of new genes for disease and pest resistance. Because $S$. ochranthum is sexually isolated from tomato, somatic hybrids between tomato (PI 367942; L. esculentum Mill. var. cerasiforme (Dunal) A. Gray VFNT cherry $x$ L. peruvianum (L.) Mill. backcrossed to VFNT cherry) and S. ochranthum (LA2117) were developed previously to overcome these crossing barriers. Attempts to backcross these hybrids to tomato have been unsuccessful. Pollen fertility and mitotic and meiotic studies in tomato $+S$. ochranthum somatic hybrids determined the cause of the sterility of the somatic hybrids and identified hybrids with moderate fertility. Chromosome counts of dividing root tip cells delineated tetraploid $(2 n=4 x=48)$ and hexaploid $(2 n=6 x=72)$ genotypes and aneuploidy in these hybrids. Meiotic analysis of developing microspores confirmed the presence of precocious division and laggard chromosomes at anaphase in both hexaploid and tetraploid hybrids. Bridges were observed in hexaploids at anaphase I and II and multivalent configurations were observed at diakinesis. Multivalents and univalents were evident in nearly all cells examined, proving that the two genomes are homoeologous. Aberrant microsporocytes with five to six developing microspores were noted in hexaploid hybrids. The occurrence of homoeologous pairing between chromosomes of both fusion parents is advantageous to effect recombination between these isolated species. However, the negative effects of multivalent formation and univalents likely contributed to observed sterility in these first generation fusion hybrids. Low to moderate levels of pollen fertility ( $0 \%$ to $52 \%)$ were found in tetraploid hybrids, while little or no viable pollen ( $0 \%$ to $4 \%)$ was observed in hexaploid somatic hybrids.
\end{abstract}

Lycopersicon Mill. is a relatively small genus within the large and varied Solanaceae. Lycopersicon consists of the cultivated tomato, L. esculentum, and eight related wild Lycopersicon sp. (Rick, 1979). The closely related genus, Solanum L., includes $\approx 1500$ species and is one of the most diverse genera of vascular plants (Hunziker, 1979). Solanum section Petota, subsection Potatoe, is the group most closely related to tomato (Rick, 1979). Subsection Potatoe is subdivided into 18 different series (Hawkes, 1979). Series Juglandifolia contains four known species, S. lycopersicoides Dunal, S. sitiens I.M. Johnst., S. ochranthum, and $S$. juglandifolium Dunal. These species are similar to Lycopersicon in that all are characteristically nontuber bearing, have pinnately divided leaves, yellow-pigmented corollas, and a somatic chromosome number of $2 \mathrm{n}=2 \mathrm{x}=24$. Within the Solanum section, $S$. lycopersicoides and $S$. sitiens represent the closest tomato relatives outside the genus Lycopersicon (Rick, 1979). Only S. lycopersicoides has been directly hybridized with tomato, although $S$. sitiens can be indirectly hybridized using $S$. lycopersicoides hybrids as a bridge (DeVerna et al., 1990). Wild Lycopersicon germplasm resources have been a valuable source of new genes for improving tomato yield, disease resistance, and fruit quality. These Solanum species further broaden the germplasm base from which breeders may identify valuable traits for tomato improvement.

Solanum ochranthum is a woody vine-like plant found mainly in very moist habitats of the northern Andes. Field observations of S. ochranthum in its native habitat and in test plots suggest this species is a potentially valuable new source of resistance to insects and bacterial and fungal diseases of foliar and root

Received for publication 3 Jan. 2001. Accepted for publication 17 June 2001. The cost of publishing this paper was defrayed in part by the payment of page charges. Under postal regulations, this paper therefore must be hereby marked advertisement solely to indicate this fact.

'E-mail: stommelj@ba.ars.usda.gov. systems for tomato improvement (Rick, 1986; Rick et al., 1990). Solanum ochranthum possesses type B glandular trichomes which may condition host resistance to small, soft-bodied arthropod pests (Tingey et al., 1981). Under controlled test conditions, Moretti et al. (1990) determined that S. ochranthum was not attacked by leafminer (Liriomyza trifolii Burgess). Research of Kobayashi et al. (1994) suggested that S. ochranthum may be a promising source of tomato late blight [Phytophthora infestans (Mont.) De Bary] resistance. Solanum ochranthum is sexually isolated from tomato, and as a result has not been utilized in tomato improvement programs. Attempts to cross S. ochranthum with tomato and nine other Lycopersicon and Solanum sp. have been unsuccessful (Rick, 1979; Rick et al., 1990).

Protoplast fusion has been used to bridge crossing barriers between Solanum species and solanaceous crop relatives. Melchers et al. (1978) first described somatic hybrids obtained from fusion of tomato and white potato (S. tuberosum L.) protoplasts. Many somatic hybrids between tomato and potato have been generated. However, fertility levels of the hybrids are very low and backcross progeny have been difficult to obtain, thus limiting their practical use (Jacobsen et al., 1994). Intergeneric somatic hybrids between tomato and a number of other Solanum species have also been reported. Somatic hybrid plants have been regenerated from fusion hybrids of $L$. esculentum and S. sitiens (O'Connell and Hanson, 1986), S. lycopersicoides (Handley et al., 1986), S. nigrum L. (Guri et al., 1988), S. acaule Bitter (Schweizer et al., 1988), $S$. muricatum Aiton (Sakomoto and Taguchi, 1991), S. etuberosum Lindl., and S. brevidens Phil. (Gavrilenko et al., 1992).

We have obtained somatic hybrids between tomato and $S$. ochranthum from fusion experiments (Kobayashi et al., 1996). Attempts to backcross $L$. esculentum $+S$. ochranthum somatic hybrids to tomato have been unsuccessful. Thus, pollen fertility and mitotic and meiotic studies in tomato $+S$. ochranthum somatic hybrids were conducted to determine the cause of sterility of the somatic hybrids. 
Table 1. Root tip chromosome counts and pollen viability of Lycopersicon esculentum, Solanum ochranthum, and L. esculentum + S. ochranthum somatic hybrids.

\begin{tabular}{|c|c|c|c|c|}
\hline $\begin{array}{l}\text { Fusion } \\
\text { parents }^{\mathrm{z}}\end{array}$ & Genotype & Ploidy & $\begin{array}{c}\text { Chromosome } \\
\text { count }\end{array}$ & $\begin{array}{c}\text { Pollen } \\
\text { fluorescence } \\
(\%)\end{array}$ \\
\hline S. ochranthum & LA 2117 & $2 \mathrm{x}$ & --- & 78.3 \\
\hline L. esculentum & PI 367942 & $2 \mathrm{x}$ & --- & 70.5 \\
\hline L. esculentum & 8611 & $2 \mathrm{x}$ & --- & 64.5 \\
\hline L. esculentum ${ }^{\mathrm{y}}$ & 8611 & $4 \mathrm{x}$ & $46-48$ & 6.5 \\
\hline \multirow[t]{6}{*}{ Ochr + 8611} & OD1-1 & $4 \mathrm{x}$ & $49-52$ & 27.7 \\
\hline & OD1-3 & $6 x$ & $70-74$ & 0 \\
\hline & OD4-5 & $6 x$ & $71^{\mathrm{x}}$ & 4.0 \\
\hline & OD6-1 & $4 \mathrm{x}$ & $47-52$ & 0 \\
\hline & OD6-36 & $6 x$ & $68^{x}$ & 0 \\
\hline & OD17-1 & $4 \mathrm{x}$ & $49-52$ & 19.6 \\
\hline \multirow[t]{6}{*}{ Ochr +367942} & OL1-1 & $4 \mathrm{x}$ & $47-48$ & 29.3 \\
\hline & OL4-1 & $4 \mathrm{x}$ & $44-48$ & 52.3 \\
\hline & OL6-2 & $4 \mathrm{x}$ & 48 & 11.6 \\
\hline & OL7-1 & $4 \mathrm{x}$ & $48-52$ & 32.6 \\
\hline & OL7-2 & $4 \mathrm{x}$ & $40-48$ & $\mathrm{ND}^{\mathrm{w}}$ \\
\hline & OL9-1 & $4 \mathrm{x}$ & $45-48$ & 12.5 \\
\hline
\end{tabular}

${ }^{\mathrm{z}}$ Abbreviations: Ochr $=$ S. ochranthum LA2117; 8611 and 367942 = L. esculentum.

yTetraploid L. esculentum, 8611, regenerant.

${ }^{\mathrm{x}}$ Count based on one cell, all other counts based on 5 to 10 cells/genotype.

${ }^{\mathrm{w}} \mathrm{ND}=$ not determined.

\section{Materials and Methods}

Plant materials. Leaf protoplasts of S. ochranthum, LA2117 $(2 \mathrm{n}=2 \mathrm{x}=24$; C.M. Rick Tomato Genetics Resource Center, University of Calif., Davis), and L. esculentum var. cerasiforme, PI $367942(2 n=2 x=24$; USDA Plant Genetic Resources Station, Geneva, N.Y.), or a L. esculentum hybrid, 8611 [(L. esculentum VFNT cherry, LA 1221 , x L. peruvianum, LA 1283-4) backcrossed to VFNT cherry], obtained from embryo callus and selected for high efficiency regeneration of shoots from callus $(2 \mathrm{n}$ $=2 \mathrm{x}=24$; D. Pratt, University of Calif., Davis) were fused with polyethylene glycol and somatic hybrid regenerants were obtained (Kobayashi et al., 1996). Hybridity of fusion regenerants was confirmed by peroxidase isozyme and randomly amplified polymorphic DNA markers (Kobayashi et al., 1996).

Cytological analysis. Root-tip meristems from developing plants were removed for chromosome counts. Excised root tips were pretreated in a solution of $0.04 \%$ 8-hydroxyquinoline for 5 to $6 \mathrm{~h}$, hydrolyzed in $1 \mathrm{~N} \mathrm{HCl}$ at $50{ }^{\circ} \mathrm{C}$ for $10 \mathrm{~min}$, fixed in a solution of 6 chloroform : $3100 \%$ ethanol : 1 glacial acetic acid (v/v) and stored at $-20^{\circ} \mathrm{C}$ in $70 \%$ ethanol until used for chromosome counts (Darlington and La Cour, 1942; McClintock, 1929). Root tips were stained in Feulgen's solution (DeTomasi, 1936). Chromosomes from up to 10 cells from several root tips of each genotype were counted using phase microscopy to determine ploidy levels.

Analysis of meiotic chromosomes in microsporocytes of developing pollen was accomplished by collecting anthers in varying stages of maturity. Anthers were fixed in $3100 \%$ ethanol : 1 glacial acetic acid (v/v) for $24 \mathrm{~h}$ and stored in $70 \%$ ethanol at -20 ${ }^{\circ} \mathrm{C}$ until analysis. Anthers were hydrolyzed in $1 \mathrm{~N} \mathrm{HCl}$ for $10 \mathrm{~min}$, macerated in $1 \%$ acetocarmine to release microsporocytes, and cells carefully squashed after gentle heating (Darlington and La Cour, 1942; McClintock, 1929).

Pollen viability. Pollen from open flowers of respective genotypes was collected in petri dishes by mechanical vibration and transferred to a germination medium supplemented with $0.001 \%$ fluorescein diacetate (FDA) in $35 \mathrm{~mm}$ plastic petri dishes, incubated for 10 to $15 \mathrm{~min}$, and pollen grain fluorescence scored using a Diaphot-TMD inverted microscope (Nikon, Imaging Systems, Columbia, Md.) with an ultraviolet (UV) light source (Abdul-Baki, 1992). Uptake and hydrolysis of FDA by viable pollen to release fluorescein, which fluoresces under UV light, discriminates viable from nonviable pollen (Heslop-Harrison and Heslop-Harrison, 1970). Pollen viability was scored in seven replicate visual fields with an average of 300 to 400 pollen grains/ field in one to three petri plates per genotype. Viability tests were performed within 1 to $2 \mathrm{~h}$ of collecting open flowers.

\section{Results and Discussion}

Chromosome counts of dividing root tip cells from somatic hybrids clearly delineated tetraploid $(2 \mathrm{n}=4 \mathrm{x}=48)$ and, within $S$. ochranthum LA2117-L. esculentum 8611 hybrids, hexaploid (2n $=6 \mathrm{x}=72$ ) genotypes (Table 1$)$. In addition, chromosome counts suggested a high degree of aneuploidy, particularly in LA21178611 hybrids (Table 1, Fig. 1F). A high percentage of aneuploid somatic hybrids obtained after symmetric hybridization between species is often reported (e.g., Masuelli et al., 1995; Wolters et al., 1994). Polysomy was confirmed via mitotic chromosome counts in four of six tetraploid and hexaploid genotypes examined from regenerants of LA2117-8611 hybrids. Aneuploidy in these regenerants may be attributable to chromosomal nondisjunction, lagging of chromosomes at anaphase, multipolar spindle forma-

Fig. 1 (right). Photomicrographs of microsporogenesis in somatic hybrids of Solanum ochranthum and Lycopersicon esculentum. (A and $\mathbf{B})$ Diakinesis in $4 \mathrm{x}$ LA2117-PI 367942 OL7-1 and (C) 6x LA2117-8611 OD1-3 showing chromosomal ring configurations with multivalents and univalents (arrows). (D) Metaphase I in 4x somatic hybrid LA2117-8611 OL7-1 showing misplaced chromatids (arrows). (E) Anaphase I in 6x LA2117-8611 OD1-3 showing bridge and laggard chromosome (arrows). (F) Aneuploid microsporocyte of $6 \mathrm{x}$ LA2117-8611OD4-5 in late anaphase I showing $\approx 74$ chromosomes. 


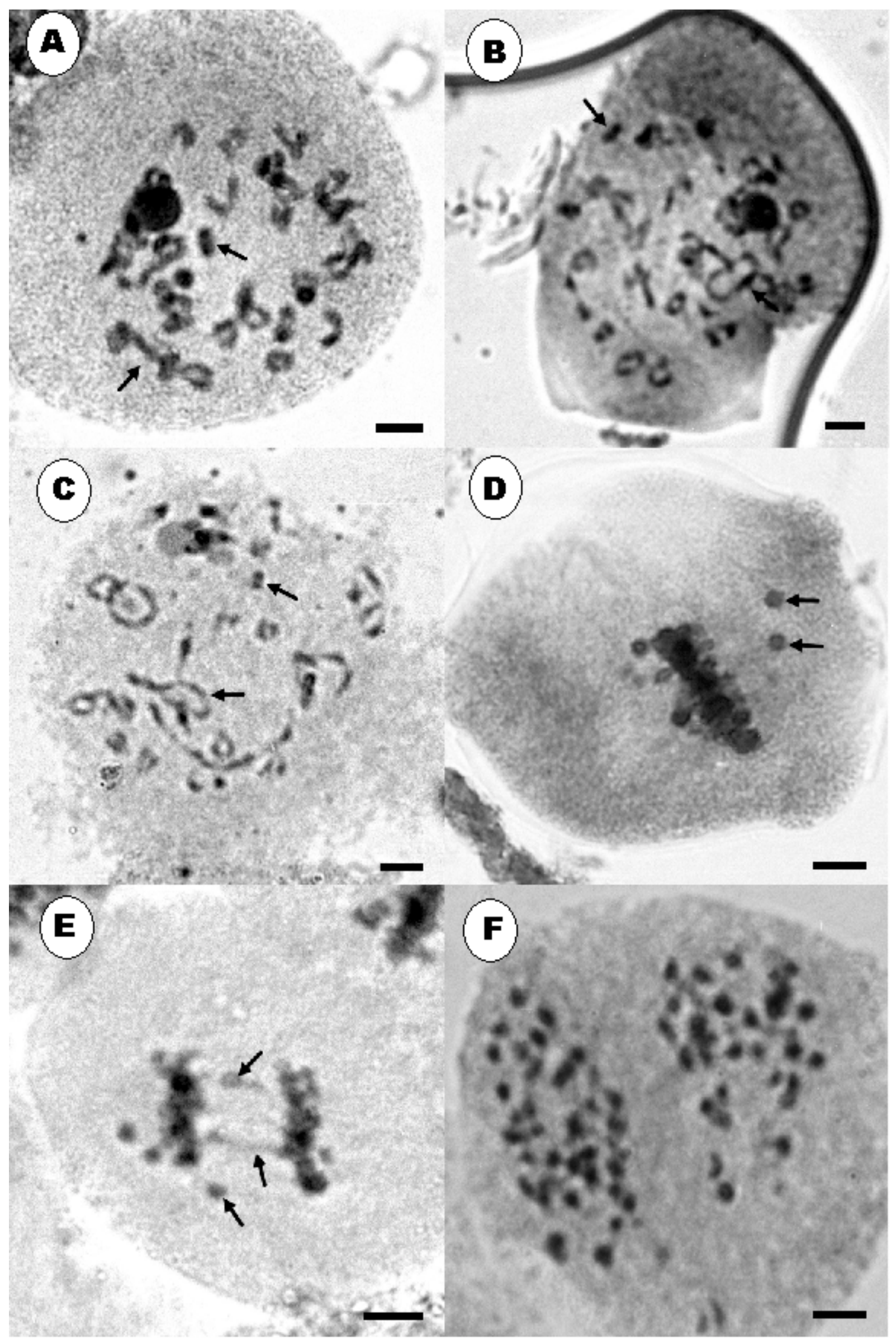




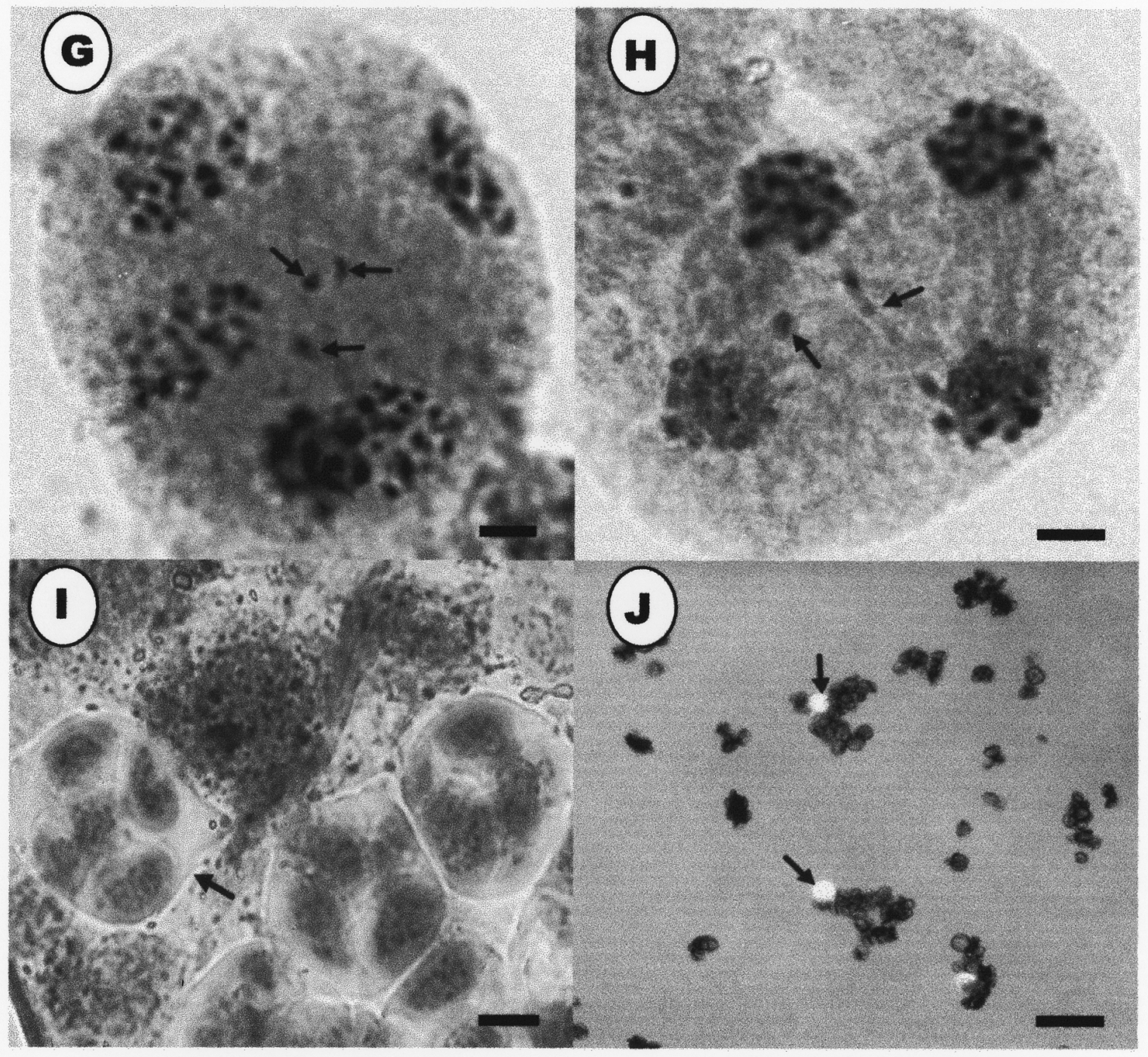

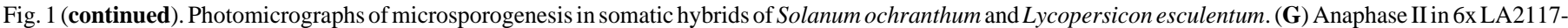

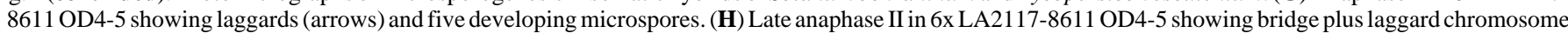
(arrows). Scale bars $=5 \mu \mathrm{m}$. (I) Aberrant microsporocyte of 6x LA2117-8611 OD4-5 in telophase II containing five microspores (arrow). Scale bar $=25 \mu \mathrm{m}$. (J) Shrunken pollen of 6x LA2117-8611 OD4-5. Viable fluorescing pollen indicated with arrows. Scale bar $=100 \mu \mathrm{m}$.

tion, or anaphase bridges resulting from rearranged, dicentric chromosomes (Sunderland, 1977). Alternatively, delayed replication owing to hybridity or in vitro conditions (Lee and Phillips, 1988; Peschke and Phillips, 1992) may deter the chromatids from separating at anaphase. Meiotic analysis of developing microspores in selected tetraploid and hexaploid somatic hybrids confirmed the presence of laggard chromosomes at anaphase and misplaced chromatids which may result from precocious division of bivalents as a consequence of multiple spindles in both hexaploid and tetraploid hybrids (Fig. 1D, E, G, and H). One to four laggards were noted in $69 \%(9 / 13)$ and $50 \%(16 / 32)$ of cells in $6 x$ LA21178611 OD1-3 and OD4-5, respectively, and 67\% (4/6) of cells in 4x LA2117-367942 OL7-1. Bridges were observed in hexaploids at anaphase I and II (Fig. 1E and H). One to four bridges were evident in 42\% (5/12) and 27\% (7/26) of cells in 6x LA2117-8611 OD1-3 and OD4-5, respectively. Multivalent configurations were also observed at diakinesis (Fig. 1A, B, and C). Where clear determinations could be made, multivalents and univalents were evident in all cells of 6x LA2117-8611 OD1-3 and OD4-5, (8/8 and $2 / 2$, respectively), and $90 \%(9 / 10)$ of cells in $4 \mathrm{x}$ LA2117367942 OL7-1.

The presence of multivalents suggested that homoeologous pairing between tomato and S. ochranthum chromosomes occurred in these hybrids. Although the occurrence of homoeologous pairing between chromosomes of both fusion parents is advantageous to effect recombination between these isolated species, the negative effects of multivalent formation and univalents likely contributed to observed sterility in these first generation fusion hybrids. Aberrant microsporocytes with five to six developing microspores were noted in 32\% (19/59) of hexaploid hybrids (Fig. 1I). The large number of chromosomes in tetraploid and hexaploid somatic hybrids, together with their small size, precluded a thorough quantitative assessment of meiotic events and accurate estimates of univalent, bivalent, and multivalent formation.

Deleterious meiotic events including chromosome breakage, translocations, and aneuploidy occur in these hybrids and contribute to sterility. Percent viable pollen as determined by fluores- 
cence in somatic hybrids was very low in comparison to parental L. esculentum and S. ochranthum lines (Table 1). Little or no viable pollen was observed in hexaploid somatic hybrids. The particular L. esculentum parent utilized in these somatic hybrids also influenced pollen viability. Pollen viability in tetraploid $S$. ochranthum +8611 somatic hybrids ranged from $0 \%$ to $43 \%$ as compared to the 8611 parent. Solanum ochranthum + PI 367942 tetraploid somatic hybrid pollen fertility was generally higher and ranged from $16 \%$ to $74 \%$ as compared to PI 367942. The relatively lower pollen viability observed in L. esculentum 8611 , in comparison to PI 367942, may be influenced by its interspecific pedigree that includes L. peruvianum. Considerable shrunken pollen was observed in lines exhibiting a high percentage of nonviable pollen (Fig. 1J). No viable pollen was detected in hexaploid LA2117-8611 OD1-3 and OD6-36 hybrids or in the OD6-1 tetraploid hybrid. It is presumed that the newly formed pollen degenerated just prior to or upon release from the tetrad stage in these somatic hybrids. Negative effects of polyploidy on pollen viability were also evident in a spontaneous tetraploid regenerant of the L. esculentum 8611 fusion parent (Table 1).

Although viable pollen was obtained in most tetraploid somatic hybrids, these hybrids were not self-fertile. In a single tetraploid somatic hybrid, OL1-1, which set several fruit upon self-pollination, only abortive seed were recovered. Attempts to reciprocally backcross tetraploid and hexaploid somatic hybrids to tomato have failed to set fruit. Backcross progeny were obtained with great difficulty from crosses between tomato + potato hexaploid somatic hybrids and tetraploid potato (Jacobsen et al., 1994). Hexaploid somatic hybrids between L. esculentum and $L$. peruvianum that were self-fertile and set viable selfed seed were described by Kinsara et al. (1986). These hybrids, however exhibited $60 \%$ irregular meiosis in pollen mother cells, resulting in low pollen viability and seed set (Giddings and Rees, 1992). Tomato $+S$. etuberosum somatic hybrids reportedly produced fruit upon self pollination, but fruit contained abortive seed (Gavrilenko et al., 1992). Somatic hybrids of tomato $+S$. lycopersicoides were reported to be fertile and develop viable seeds upon selfing (Hossain et al., 1994).

Further introgression of the genetic variation present in $S$. ochranthum into the tomato genome is necessary to exploit this sexually isolated species in tomato improvement programs. The occurrence of low to moderate levels of fertility in our somatic hybrids is encouraging. However, the difficulty of attaining initial backcross generations from intergeneric hybrids is well illustrated in combinations between tomato and white potato (Jacobsen et al., 1994) and tomato and S. lycopersicoides (Gradziel and Robinson, 1989). Gradziel and Robinson (1989) obtained a small number of backcross progeny via selection of intergeneric hybrids with sufficient pollen fertility or by applying a variety of pollination techniques to circumvent crossing barriers. Utilizing bridging hybrids as pollen parents, Chetelat et al. (1989) were able to obtain relatively large numbers of backcross progeny from the unilaterally incompatible and male-sterile tomato $\times S$. lycopersicoides hybrid; an intergeneric hybrid with partial male fertility was also backcrossed directly to L. esculentum (Chetelat and Meglic, 2000). Adoption of this approach for S. ochranthum is limited by its apparently complete reproductive isolation (Rick, 1979). Jacobsen et al. (1994) found that fruit and seed set were greatly enhanced in backcrosses between tetraploid potato and hexaploid somatic hybrids of potato + tomato, in comparison to tetraploid potato crossed to tetraploid somatic hybrids, and that selection of good combining female somatic hybrids and pollina- tors enhanced set. Strategies such as these may facilitate generation of successful backcross progeny from tomato + S. ochranthum somatic hybrids. Only when successful backcross progeny with these somatic hybrids can be obtained, will recombination between homoeologous chromosomes of these two species be of practical use.

\section{Literature Cited}

Abdul-Baki, A.A. 1992. Determination of pollen viability in tomatoes. J. Amer. Soc. Hort. Sci. 117:473-476.

Chetelat, R.T. and V. Meglic. 2000. Molecular mapping of chromosome segments introgressed from Solanum lycopersicoides into cultivated tomato (Lycopersicon esculentum). Theor. Appl. Genet. 100:232-241.

Chetelat, R.T., C.M. Rick, and J.W. DeVerna. 1989. Isozyme analysis, chromosome pairing, and fertility of Lycopersicon esculentum $\mathrm{x}$ Solanum lycopersicoides diploid backcross hybrids. Genome 32:783790.

Darlington, C.D. and L.F. La Cour. 1942. Handling of chromosomes. George Allen and Unwin, London.

DeTomasi, J.A. 1936. Improving the technique of the Feulgen stain. Stain Technol. 11:137-144.

DeVerna, J.W., C.M. Rick, R.T. Chetelat, B.J. Lanini, and K.B. Alpert. 1990. Sexual hybridization of Lycopersicon esculentum and Solanum rickii by means of a sesquidiploid bridging hybrid. Proc. Natl. Acad. Sci. USA 87:9486-9490.

Gavrilenko, T.A., N.I. Barbakar, and A.V. Pavlov. 1992. Somatic hybridization between Lycopersicon and non-tuberous Solanum species of the Etuberosa series. Plant Sci. 86:203-214.

Giddings, G.D. and H. Rees. 1992. The cytology of Lycopersicon somatic hybrids. Proc. Royal Soc. London Series B Biol. Sci. 248:6367.

Gradziel, T.M. and R.W. Robinson. 1989. Solanum lycopersicoides gene introgression into tomato, Lycopersicon esculentum, through the systematic avoidance and suppression of breeding barriers. Sexual Plant Reprod. 2:43-52.

Guri, A., A. Levi, and K.C. Sink. 1988. Morphological and molecular characterization of somatic hybrid plants between Lycopersicon esculentum and Solanum nigrum. Mol. Gen. Genet. 212:191-198.

Handley, L.W., R.L. Nickels, M.W. Cameron, P.P. Moore, and K. Sink. 1986. Somatic hybrid plants between Lycopersicon esculentum and Solanum lycopersicoides. Theor. Appl. Genet. 71:691-697.

Hawkes, J.G. 1979. Evolution and polyploidy in potato species, p. 637645. In: J.G. Hawkes, R.N. Lester, and A.D. Skelding (eds.). The biology and taxonomy of the Solanaceae. Academic Press, New York. Heslop-Harrison, J. and Y. Heslop-Harrison. 1970. Evaluation of pollen viability by enzymatically induced fluorescence: Intracellular hydrolysis of fluorescein diacetate. Stain Technol. 45:115-120.

Hossain, M., S. Imanishi, and A. Matsumoto. 1994. Production of somatic hybrids between tomato (Lycopersicon esculentum) and nightshade (Solanum lycopersicoides) by electrofusion. Breeding Sci. 44:405-412.

Hunziker, A.T. 1979. South American Solanaceae: A synoptic survey, p. 49-85. In: J.G. Hawkes, R. N. Lester and A.D. Skelding (eds.). The biology and taxonomy of the Solanaceae. Academic Press, New York. Jacobsen, E., M.K. Daniel, J.E.M. Bergervoet-van Deelen, D.J. Huigen, and M.S. Ramanna. 1994. The first and second backcross progeny of the intergeneric fusion hybrids of potato and tomato after crossing with potato. Theor. Appl. Genet. 88:181-186.

Kinsara, A., S.N. Patnaik, E.C. Cocking, and J.B. Power. 1986. Somatic hybrid plants of Lycopersicon esculentum Mill. and Lycopersicon peruvianum Mill. J. Plant Physiol. 125:225-234.

Kobayashi, R.S., K.D. Deahl, J.R. Stommel, and S. L. Sinden. 1994. Evaluation of Solanum ochranthum as a potential source of late blight resistance. Tomato Genet. Coop. Rpt. 44:15-16.

Kobayashi, R.S., J.R. Stommel, and S. L. Sinden. 1996. Somatic hybridization between Solanum ochranthum and Lycopersicon esculentum. Plant Cell Tiss. Org. Cult. 45:73-78. 
Lee, M. and R.L. Phillips. 1988. The chromosomal basis of somaclonal variation. Annu. Rev. Plant Physiol. Plant Mol. Biol. 39:413-437.

Masuelli, R.W., E.Y. Tanimoto, and C.R. Brown. 1995. Irregular meiosis in a somatic hybrid between $S$. bulbocastanum and S. tuberosum detected by species-specific PCR markers and cytological analysis. Theor. Appl. Genet. 91:401-408.

McClintock, B.A. 1929. A method for making acetocarmine smears permanent. Stain Technol. 4:53-56.

Melchers, G., M.D. Sacristan, and A.A. Holder. 1978. Somatic hybrid plants of potato and tomato regenerated from fused protoplasts. Carlsberg Res. Commun. 43:203-218.

Moretti, A., H. Laterrot, and D. Bordat. 1990. Observations of Solanum ochranthum and S. juglandifolium. Tomato Genet. Coop. Rpt. 40:25.

O'Connell, M.A. and M.R. Hanson. 1986. Regeneration of somatic hybrid plants formed between Lycopersicon esculentum and Solanum rickii. Theor. Appl. Genet. 72:59-65.

Peschke, V.M. and Phillips, R.L. 1992. Genetic implications of somaclonal variation in plants. Adv. Genet. 30:41-75.

Rick, C.M. 1979. Biosystematic studies in Lycopersicon and closely related species of Solanum, p. 667-678. In: J.G. Hawkes, R.N. Lester, and A.D. Skelding (eds.). The biology and taxonomy of the Solanaceae. Academic Press, New York.
Rick, C.M. 1986. Germplasm resources in the wild tomato species. Acta Hort. 190:39-47.

Rick, C.M., J.W. DeVerna, and R.T. Chetelat. 1990. Experimental introgression to the cultivated tomato from related wild nightshades, $p$. 19-30. In: A.B. Bennett and S.D. O'Neill (eds.). Horticultural biotechnology. Wiley-Liss, New York.

Sakomoto, K. and T. Taguchi. 1991. Regeneration of intergeneric somatic hybrid plants between Lycopersicon esculentum and Solanum muricatum. Theor. Appl. Genet. 81:509-513.

Schweizer, G., M. Ganal, H. Ninnemann, and V. Hemleben. 1988. Species-specific DNA sequences for identification of somatic hybrids between Lycopersicon esculentum and Solanum acaule. Theor. Appl. Genet. 75:379-384.

Sunderland, N. 1977. Nuclear cytology, p. 177-205. In: H.E. Street (ed.). Plant tissue and cell culture. Blackwell, Oxford, United Kingdom.

Tingey, W.M., S.A. Mehlenbacher, and J.E. Laubengayer. 1981. Occurrence of glandular trichomes in wild Solanum species. Amer. Potato J. 58:81-83.

Wolters, A.M.A., H.C.H. Schoenmakers, S. Kamstra, J. Van Eden, M. Koornneef, and J.H. de Jong. 1994. Mitotic and meiotic irregularities in somatic hybrids of Lycopersicon esculentum and Solanum tuberosum. Genome 37:726-735. 